\title{
A Future of Mess, Confusion and Complexity? Linking Children's Rights and Knowledge Management in a Critical Research Agenda beyond 25 years of the Convention on the Rights of the Child
}

Sara Lembrechts

\section{Introduction}

\subsection{Setting the scene}

The twenty-fifth anniversary of the Convention on the Rights of the Child (CRC) provided an ideal opportunity for researchers, policy-makers and practitioners to take stock of where we stand with children's rights. What can we learn from the past quarter century that makes us push the boundaries of today towards an innovative future with more social justice and human dignity for children? Why have efforts to further the realisation of children's human rights often been fragmented and ineffective, despite the great progress being made in theory and practice?

The chapter uses this momentum to address two interrelated dilemmas at the heart of the children's rights debate: (1) the inherent complexity of children's rights, which militates against a shared understanding of social problems and their solutions, and (2) the fragmentation of knowledge, which prevents better outcomes in a society where we are 'information rich and time poor'. ${ }^{1}$ To critically address these challenges, the chapter will initiate a dialogue between two research fields that have so far seldom been connected - children's rights and knowledge management (KM). Whereas KM is understood as the multidisciplinary approach to achieving social objectives by making the best use of knowledge ${ }^{2}$ children's rights are defined as fundamental claims for the realisation of the social objectives of justice and human dignity for children. ${ }^{3}$

The chapter builds on materials and insights that were gathered from activities of the Flemish Children's Rights Knowledge Centre (in Dutch, Kenniscentrum Kinderrechten $v z w$, abbreviated as $\mathrm{KeKi}$ ). Operational since 2010, KeKi aims to gather, make available, disseminate, stimulate and increase knowledge on children's rights. Usually, this knowledge is generated by national and international academic research ${ }^{4}$ and is intended for researchers from multiple academic disciplines, policy-makers and practitioners working on matters concerning youth and children's rights. As a nonprofit organisation, financially supported by the Flemish Government and substantively backed up by a multidisciplinary, inter-university platform of researchers in Belgium, $\mathrm{KeKi}$ occupies a unique position at the intersection of these three domains of research,

\footnotetext{
${ }^{1}$ Head B 'From knowledge transfer to knowledge sharing?' in Bammer G, Michaux A \& Sanson A (eds) Bridging the 'Know-Do' Gap: Knowledge Brokering to Improve Child Wellbeing (2010) 109.

2 Cf. Girard J Knowledge Management (KM) Definitions (2015), available at http://www.johngirard.net/km (accessed 13 January 2015).

${ }^{3}$ Cf. Reynaert D, Desmet E, Lembrechts S \& Vandenhole W 'Introduction: a critical approach to children's rights' in Vandenhole W, Desmet E, Reynaert D \& Lembrechts S (eds) Routledge International Handbook of Children's Rights Studies (2015).

${ }^{4}$ Increasingly, however, the use of knowledge stemming from non-academic sources is gaining ground as well (see, for example, the first edition of Research on Stage at http://www.keki.be/research-stage).
} 
policy and practice. Moreover, due to its growing role as an independent knowledge actor, on the one hand, and a bridge, broker and knowledge co-creator between research, policy and practice, on the other, ${ }^{5} \mathrm{KeKi}$ 's know-how is considered a useful point of reference.

\subsection{Methodology and limitations}

The bulk of results presented below are the product of a multidisciplinary desktop study in which children's rights, knowledge management and possible synergies between the two were subjected to a critical literature review. In addition, over a period of two years (2012-2014), KeKi held formal and informal ${ }^{6}$ expert consultations with stakeholders from a wide range of children's rights institutions in Flanders, so as to be able to complement the theoretical insights with qualitative data. ${ }^{7}$

In particular, KeKi organised and moderated three focus group discussions, each with a mixed group of six to eight representatives from children's rights research $(n=8)$, policy $(n=5)$ and practice $(n=9)$ in November and December 2013. To guarantee equal access for participants, the first focus group (F1) took place in Brussels, the second (F2) in Ghent and the third (F3) in Antwerp. Out of 22 participants, one was professionally active in the Netherlands, while the others travelled from Antwerp, Brussels, Ghent and Leuven (Belgium). Participants received a personal invitation based on their membership of KeKi's Advisory Board and/or on their previous involvement with other KeKi activities. ${ }^{8}$

The aim of the focus groups was to offer an open forum to brainstorm the way in which knowledge on children's rights is researched, obtained and shared among professionals in different working environments. In all three discussions, which each lasted about two hours, participants reflected on the needs (gaps), wishes (bridges) and good practices in translating knowledge between various actors, as well as on how we can, through continuous dialogue, look for new solutions and strategies when co-creating knowledge to address complex social problems. The discussions were transcribed and analysed using a Grounded Theory approach (Glaser \& Strauss (1967)). References to the different discussions are made in parentheses, referring to one or more sessions (F1,

\footnotetext{
5 This role was formally strengthened and reaffirmed when KeKi entered its second beleidsperiode (policy period) in January 2014.

${ }^{6}$ Previous drafts of this study were discussed at the conference Children and Young People Active in Scientific Research of the Dutch-Flemish Platform for Child Participation in Research (Leiden, 4 April 2013), with KeKi's Advisory Board (Brussels, 24 April 2013), at KeKi's seminar Mind the Bridge: the Children's Rights Database as a bridge between research, policy and practice (Brussels, 6 June 2013) and at the conference 25 Years CRC (Leiden, 18-19 November 2014). The latter two presentations can be consulted at http://www.keki.be.

${ }^{7} \mathrm{As} \mathrm{KeKi}$ is a learning organisation, all collected input has served - and continues to do so - as food for thought for an ongoing project of fine-tuning KeKi's 'bridging' expertise.

8 Including, but not limited to, members of the test group of the Children's Rights Database (Kinderrechtendatabank), editors of the scientific board of the Youth \& Children's Rights Journal (TJK), addressees of KeKi's policy advice, and participants of KeKi’s training programmes.
} 
F2 or F3) and indicating the timeslot (for example, 15:44-17:00) where the information can be found in the corresponding transcription. ${ }^{9}$

The possibility of involving children in the research process was closely examined but not pursued. Although there was awareness that obtaining knowledge on children's life worlds without the active participation of children runs the risk of being incomplete, ${ }^{10}$ the predominantly theoretical perspective taken in this chapter did not lend itself to involving children. ${ }^{11}$ Time and resources were insufficient to develop the necessary expertise and create the preconditions to guarantee that participation would be meaningful, genuine and effective. ${ }^{12}$ This does not mean, however, that the chapter is not reflexive about such issues as the (im)balances of power, agency and voice of children in matters affecting them; on the contrary, they have been incorporated at various points in what follows.

\subsection{Overview}

The dialogue between children's rights and knowledge management is explored in two research questions: (1) How could the children's rights field learn from KM so as to become better equipped to deal with the complexity inherent in the realisation of children's rights in young people's daily lives? (2) Conversely, how should these models of KM be adapted to work specifically in a children's rights context? To answer the questions, section two introduces the KM notion of 'complex problems' to open new perspectives on what it means for stakeholders from research, policy and practice to work towards realising children's rights. Section three analyses the potential and challenges of three KM strategies for children's rights professionals, namely, knowledge sharing, knowledge brokering and knowledge co-creation. Finally, the discussion in section four expands on what lessons children's rights can teach to KM in terms of the participation and social agency of children.

\section{Defining children's rights as a complex problem}

Despite the great expectations and unprecedented opportunities that came with the global adoption of the $\mathrm{CRC}$, children's rights researchers, policy-makers and practitioners face a wide range of issues that remain extremely difficult to solve. Eradicating all forms of violence against children and realising the rights of children from poor families, of children without parental care, working children, children in

\footnotetext{
${ }^{9}$ Transcriptions (in Dutch), a list of participants and further details about the focus groups can be requested from the author.

${ }^{10}$ Dedding C, Jurrius K, Moonen X \& Rutjes L (eds) Kinderen en jongeren actief in wetenschappelijk onderzoek. Ethiek, methoden en resultaten van onderzoek met en door jeugd (2013) 14; see also F3, 1:24:36-1:26:39.

${ }^{11}$ This conclusion was reached during an informal consultation with experts from Kind \& Samenleving (April 2013). See also Percy-Smith B \& Thomas N (eds) A Handbook of Children and Young People's Participation: Perspectives from Theory and Practice (2009) 3.

${ }^{12}$ Hart R Children's Participation: From Tokenism to Citizenship (1992) 9. All three focus groups confirmed the widespread concern that often time and resources are lacking to include young people's experiences.
} 
conflict with the law or any other children and young people who find themselves in marginalised or subordinate positions in society, confront us with mess, confusion and complexity. Since much has been written and said elsewhere about the urgency of these issues, the goal of this chapter is not to address them substantively. Rather, it will be argued that taking a fresh perspective through the lens of knowledge management may encourage children's rights professionals to think outside the box of our conventional paradigms, inspiring us to be self-critical and look for innovative approaches in problem-solving.

In particular, a KM perspective invites us to consider that a common denominator to the abovementioned problems related to children's rights is their unstructured and complex nature. Such 'complex problems' entail multiple challenges. ${ }^{13}$ One challenge lies in the fact these problems act on several systemic levels. Responsibility is placed with a variety of actors, which often leads to ambiguity as to who is responsible for what. ${ }^{14}$ In addition, complex problems fall back neither on a consensus about the problem definition, nor on the most suitable direction for a solution. Often, complex problems also contain a dimension of power and cause disagreement on how practical interventions can be effectively implemented.

Trying to understand these 'complex problems' with the aim of contributing to a possible solution requires non-conventional approaches. ${ }^{15}$ For one, this holds true on the level of substance, that is, of knowledge about children's rights. Even though this substantive level is not the primary focus of the chapter, it is useful to briefly situate this debate in the current state of children's rights studies. In particular, taking the complexity of children's rights as a starting-point challenges the dominant paradigms that have long governed knowledge building on children's rights. These paradigms tend to take the CRC as a key point of reference, defining children's rights as a universal, objective and fairly undisputed set of principles, neutral to the context in which children grow up and uncritical about the diversity of meanings children's rights may have in different contexts. ${ }^{16}$ In response to that, recent scholarship increasingly points out that the reality of children's rights is much more complex than a legal instrument and its implementation. ${ }^{17}$ Taking a contextualised and interdisciplinary approach, these critical

\footnotetext{
${ }^{13}$ Head R 'From knowledge transfer to knowledge sharing?' in Bammer G, Michaux A \& Sanson A (eds) Bridging the 'Know-Do' Gap: Knowledge Brokering to Improve Child Wellbeing (2010) 110; Bammer G, Michaux A \& Sanson A Bridging the 'Know-Do' Gap: Knowledge Brokering to Improve Child Wellbeing (2010) xix; Regeer BJ \& Bunders JFG Kenniscocreatie: samenspel tussen wetenschap \& praktijk: Complexe, maatschappelijke vraagstukken transdisciplinair benaderd (2007) 18.

${ }^{14}$ See also F2, 46:50-47:44; F3, 41:34-42:09, 43:24-46:00.

${ }^{15}$ Regeer BJ \& Bunders JFG Kenniscocreatie: samenspel tussen wetenschap \& praktijk: Complexe, maatschappelijke vraagstukken transdisciplinair benaderd (2007) 11.

${ }^{16}$ Reynaert D, Desmet E, Lembrechts S \& Vandenhole W 'Introduction: a critical approach to children's rights' in Vandenhole W, Desmet E, Reynaert D \& Lembrechts S (eds) Routledge International Handbook of Children's Rights Studies (2015) 2.

17 See, in particular, Liebel (2012) on children's rights from below; Vandenhole (2012) on localising children's rights; Reynaert (2010) on a life-world approach to children's rights; and Hanson \& Nieuwenhuys (2013) on children's rights as living rights.
} 
theories make explicit how universal understandings of children's rights are in constant interplay both with the local particularities of children's lived realities as well as with the interests of other social groups.

Secondly, and as the main focus of this chapter, non-conventional approaches are required on the process level as well, that is, in relation to approaches to knowledge on children's rights. In particular, experience and know-how from practice, data or legislation collected at policy level, and academic research stemming from rigorous methodological and disciplinary choices, have proven to be insufficient to deal with complex problems when used as knowledge in isolation. ${ }^{18}$ Notably, the essence of what it means to realise children's rights implies very different things to different people. As such, it is clear that, apart from the role played by substantive complexity, this procedural form of complexity also hinders shared understanding of the social problem of realising children's rights and, consequently, of the solution that should be envisaged. ${ }^{19}$

To some extent, children's rights professionals have already sought a considerable degree of cooperation and connectedness to meet that concern. More and more, nongovernmental organisations (NGOs) and practitioners join forces in local and global coalitions, while at the same time it is between administrations across geographical borders that much of children's rights policy-making is given shape. In addition, researchers in this field are increasingly invited not to stick to one field of study only. Cutting across multiple disciplines, children's rights allow scholars to explore inter-, multi- and trans-disciplinary forms of cooperation with colleagues from other backgrounds. $^{20}$

As such, however, these islands all too often have remained islands, in the sense that bridges are being built within rather than between children's rights research, policy and practice. Furthermore, strategies, ideas and methods on how to translate different forms of knowledge between research, policy and practice have remained relatively unexplored from a children's rights perspective, both in terms of theoretical models and concrete examples from practice. In other domains of expertise, though, helpful suggestions have been shared as to how such bridges could be built. ${ }^{21}$ Whereas most of

\footnotetext{
${ }^{18}$ Crow MM 'None dare call it hubris: the limits of knowledge' (2007); Regeer BJ \& Bunders JFG Kenniscocreatie: samenspel tussen wetenschap \& praktijk: Complexe, maatschappelijke vraagstukken transdisciplinair benaderd (2007) RMNO report.

${ }^{19}$ Bammer G, Michaux A \& Sanson A Bridging the 'Know-Do' Gap: Knowledge Brokering to Improve Child Wellbeing (2010) xix.

${ }^{20}$ Reynaert D, Desmet E, Lembrechts S \& Vandenhole W 'Introduction: a critical approach to children's rights' in Vandenhole W, Desmet E, Reynaert D \& Lembrechts S (eds) Routledge International Handbook of Children's Rights Studies (2015) 8-9; Regeer BJ \& Bunders JFG Kenniscocreatie: samenspel tussen wetenschap \& praktijk: Complexe, maatschappelijke vraagstukken transdisciplinair benaderd (2007) RMNO report, 11; F1, 1:22:41-1:23:30, 1:25:17.

${ }^{21}$ For example: studies, publications and projects in public health (Comiskey (2012), Waddell (2001)), youth and family services (Bammer et al. (2010), Lewig et al. (2006), Shonkoff (2000), Hermans \& Van
} 
these initiatives do not touch the issue of children's rights at all, it is worthwhile to explore to what extent the collected insights from other complex problems can be applied to a children's rights context.

\section{Dealing with mess, confusion and complexity: lessons from KM for children's rights}

Knowledge is a moving target. ${ }^{22}$ Even more so when complex problems are concerned, knowledge is changed, rearranged, updated and contested continuously. Making the best use of knowledge as a resource to achieve further realisation of children's rights thus requires a continuous dynamism. This section will explore the way in which three types of knowledge management strategies - knowledge sharing, knowledge brokering and knowledge co-creation - can help children's rights professionals to deal with that complexity in a dynamic way.

\subsection{Building bridges to share and broker existing knowledge}

Strategies of sharing and brokering start from the assumption that 'barriers to knowledge use' create 'gaps' between different stakeholders, which, when 'bridged' with 'connective tissue', will contribute to a more relevant knowledge base to underpin present and future children's rights research, policy and practice. ${ }^{23}$ In the literature as well as in the focus groups, bridging these gaps and opening a discussion on how to do so, turned out to be a unanimous concern.

First, 'knowledge sharing' refers to communication and dissemination strategies where experts from research, policy or practice come out with their own knowledge in an attempt to 'share' it with their partners in other domains. As such, they change the format of their knowledge to make sure that what they consider to be useful gets to their partners in an adequate format. Figure 1 illustrates how one type of knowledge (KN1) is bridged from one actor (left) to another (right), and how this can work in both directions.

Regenmortel (2013)); global development (Court \& Young (2003, 2004)); information management (Kazi et al. (2007), Earl (2001)); social sciences (Caplan (1979); and environmental sciences (Magnuszewski et al. (2010), Crow (2007), Regeer \& Bunders (2007)).

${ }^{22}$ Shonkoff JP 'Science, policy and practice: three cultures in search of a shared mission' (2000) Child Development 71(1), 187.

${ }^{23}$ Harper C, Jones N \& Tincati C 'Opportunities and challenges in promoting policy- and practicerelevant knowledge on child rights' (2010) ODI Working Paper 318, 1; Lewig K, Arney F \& Scott D 'Closing the research-policy and research-practice gaps: ideas for child and family services' (2006) Family Matters 74, 14; Waddell C 'So much research evidence, so little dissemination and uptake: mixing the useful with the pleasing' (2001) Evidence Based Mental Health 4(1), 4. 


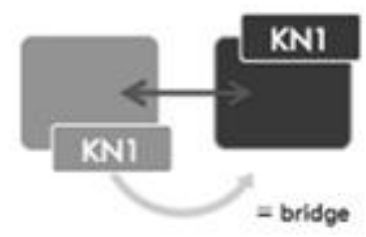

Concretely, a change in format implies that one finds a bridge in the way knowledge is translated from the 'language' of one actor to that of another. A youth worker, for example, may participate in a study on good practices in youth care. By doing so, the practical experience of the youth worker is translated from know-how into data. Researchers, in turn, may then translate these results into policy recommendations for an improved youth policy, or help in the construction of useful tools for other youth workers.

Bridges can be of different design, material and solidity depending on the gap they seek to overcome. This also implies that the 'gaps' to be bridged can take multiple forms. Usually, they refer to cross-cutting barriers or 'cultural differences' 24 between knowledge producers in research, policy and practice. ${ }^{25}$ These include using different forms of evidence and datasets, different needs, ${ }^{26}$ different missions and agendas, ${ }^{27}$ different language conventions, ${ }^{28}$ different considerations of priority, different preferences for structuring and different interpretations of relevance and truth. ${ }^{29}$

As all focus groups confirm, being responsible for sharing your knowledge is not an easy task. Knowledge producers often face personal or structural hurdles when wanting to make 'their' knowledge available - for example, through databases, reporting services, summaries, publications in scientific journals directed to a wide audience, and so forth. Not every individual in research, policy or practice has the enthusiasm and basic networking and entrepreneurial skills necessary for building a successful bridge. ${ }^{30}$

\footnotetext{
${ }^{24}$ Shonkoff JP 'Science, policy and practice: three cultures in search of a shared mission' (2000) Child Development 71(1), 181-7.

${ }^{25}$ Regeer BJ \& Bunders JFG Kenniscocreatie: samenspel tussen wetenschap \& praktijk: Complexe, maatschappelijke vraagstukken transdisciplinair benaderd (2007) RMNO report, 12.

${ }^{26}$ For example, practitioners tend to seek knowledge that leads to action, where the robustness and profundity of the academic world is neither necessary nor desirable (F1, 44:20-49:40, F2, 25:49-26:42).

${ }^{27}$ Researchers are, for example, not always in a position to make recommendations on policy. They may be unable or unwilling to take a political stance that could compromise their position of neutrality, in which they seek the highest possible degree of nuance and objectivity (F1, 50:57-52:29; F2, 24:12-24:44, 45:59-46:50; F3, 43:24-46:00).

${ }^{28}$ Jargon, for example, is often a hurdle (F1, 05:12-06:25, 09:22, 1:24:56).

${ }^{29}$ Lewig K, Arney F \& Scott D 'Closing the research-policy and research-practice gaps: ideas for child and family services' (2006) Family Matters 74, 14; Stone D 'Using knowledge: the dilemmas of 'bridging research and policy' (2002) Compare 32(3), 295; Shonkoff JP 'Science, policy and practice: three cultures in search of a shared mission' (2000) Child Development 71(1), 181-2.

${ }^{30}$ Young J 'Working with complexity: impact of research on policy and practice' (2008) Capacity 35; F2, 1:37:14-1:38:49.
} 
Furthermore, even if personal qualities and skills are not an issue, a lack of time and financial resources often stands in the way. ${ }^{31}$

An option to partly overcome that challenge is to consider the role of external knowledge brokers. ${ }^{32}$ Unlike knowledge sharing, knowledge brokering does not depend to such a great extent on stakeholders' own initiative, but instead involves intermediaries or 'brokers' to bridge knowledge between the producers (supply) and the users (demand) of knowledge. A broker identifies knowledge of relevance to a party (KN1) and then transfers that knowledge in an appropriate form from one stakeholder to another $(\mathrm{KN} 2) .{ }^{33}$ The knowledge gets transformed in a way that makes it more reader-oriented, and thus more relevant and meaningful to other parties (Figure 2).

Figure 2: Knowledge brokering between two or more actors

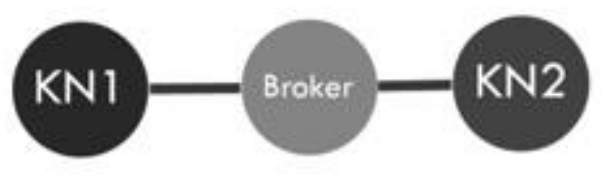

Brokers can play a pivotal role in the bridging process, not only in separating chaff (poor standards, irrelevant and low-quality knowledge) from wheat (rigorous, useful and high-quality knowledge), but in overcoming resistance, reframing, matchmaking, engaging, collaborating, capacity-building, moderating, facilitating, interacting and cross-fertilising between research, policy and practice. ${ }^{34}$

Around the world, one can identify a number of formal or informal networks or specialised agencies that create such forums for knowledge brokering across research, policy and practice. The UNICEF Office of Research - Innocenti - is one example

\footnotetext{
${ }^{31}$ Even if researchers seek from the very start to bridge the know-do gap, the outcomes of such processes are usually unpredictable, which makes it hard to obtain funding in the first place (F2, 1:33:23-1:33:40). Furthermore, policy-oriented research in particular looks for fast and preferably numerical results, that is, something a participatory approach will generally not offer (F3).

${ }^{32}$ Even though the concept of knowledge brokering - which originates in organisation theory and financial market analysis - is not without limits for the social sciences, Marsh (2012) has previously applied it to childhood studies, and Bammer et al. have used it in the context of youth well-being.

${ }^{33}$ Marsh J 'Children as knowledge brokers of playground games and rhymes in the new media age' (2012) Childhood 19(4), 511; Comiskey C Developing and implementing a model to bridge the gap in policy research and practice (2012); Magnuszewski P, Sodomkova K, Slob A, Muro M, Sendzimir J \& Pahl-Wostl C Report on Conceptual Framework for Science-Policy Barriers and Bridges (2010); Sin $\mathrm{Chih} \mathrm{H}$ 'The role of intermediaries in getting evidence into policy and practice: some useful lessons from examining consultancy-client relationships' (2008) Evidence \& Policy: A Journal of Research, Debate and Practice 4(1), 85-103.

${ }^{34}$ Magnuszewski P, Sodomkova K, Slob A, Muro M, Sendzimir J \& Pahl-Wostl C Report on Conceptual Framework for Science-Policy Barriers and Bridges (2010) 23, 28-30; Kazi AS, Wohlfahrt L \& Wolf P (eds) Hands-On Knowledge Co-Creation and Sharing: Practical Methods and Techniques (2007) vii; UNICEF Progress Report and Proposed Activities for 2006-2008 (2005) 18.
} 
(UNICEF (2005)), and KeKi aims to fulfil this role as well. ${ }^{35}$ In practice, brokering takes place on various levels, combined or used in isolation. Brokers, for example, may circulate soft or hard copies of textual documents that summarise knowledge without being simplistic ${ }^{36}$ or provide a platform where knowledge producers can publish their own materials. ${ }^{37}$ Alternatively, brokering may entail facilitating personal interaction between stakeholders, ${ }^{38}$ by building relationships of trust between individuals ${ }^{39}$ or by providing researchers with a platform to present and discuss their findings on a certain issue with practitioners and policy-makers. ${ }^{40}$ Online technology has also played a major part in the development and spread of knowledge brokering, for example in providing a children's rights database $\mathrm{e}^{41}$ or online exchange of expertise.

These activities go beyond the mere sharing, transmitting or moving of existing knowledge from one actor to another. The knowledge that crossed the broker bridge is not the same on the one side as it was on the other - it is transformed to a new type of knowledge 'that has been de- and reassembled', knowledge that has been 'made more robust, more accountable, more usable'. ${ }^{42}$ Moreover, this new, brokered knowledge comes to '[serve] locally at a given time', ${ }^{43}$ herewith responding - at least in part - to the substantive complexity of children's rights briefly referred to in section two.

\subsection{Co-creating new knowledge}

When we talk about complex problems in our above-agreed definition of the term, casual networking and exchange of existing knowledge, be it shared or brokered, is often not sufficient in cases of mess, confusion and complexity. In these cases, KM can also go one step further, in that, notably through processes of knowledge co-creation, it helps to establish a form of shared ownership of new strategies and new knowledge on possible solutions to complex problems.

\footnotetext{
35 In the past, the Norway-based Childwatch International Research Network has played a major brokering role in the field of children's rights too. However, the network is currently on hold due to a lack of funding for its secretariat.

${ }^{36} \mathrm{~F} 1,44: 20-50: 13,56: 07-56: 35 ; \mathrm{F} 2,34: 53-35: 40,49: 42-50: 38,1: 05: 10-1: 07: 02$.

${ }^{37}$ For example, in the Flemish Tijdschrift voor Jeugd en Kinderrechten (Journal for Youth and Children's Rights), TJK publishes contributions (mostly in Dutch) that critically reflect on developments in the field of youth and children's rights, in different disciplines, sectors and contexts. In the section Forumtekst (forum text), the journal gives the floor to practitioners and policy-makers to share non-academic opinionated contributions written in their personal capacity or in the name of an organisation.

${ }^{38}$ F1, 1:15:27-1:15:36, 1:33:37-1:33:53; F2, 23:14-24:12, 27:49-28:14; F3, 31:08.

${ }^{39} \mathrm{~F} 1,1: 40: 04-1: 40: 19 ; \mathrm{F} 3,1: 11: 12-1: 14: 05$.

${ }^{40}$ For example: with Research on Stage, KeKi facilitates the translation of current children's rights research by giving the floor to young researchers addressing a wide audience of practitioners, policymakers and other researchers about their findings.

${ }^{41}$ For example, in KeKi's database, researchers can complete a file about their research project and have it put online for other researchers, practitioners and policy-makers to consult (www.kekidatabank.be).

${ }^{42}$ Meyer M 'The rise of the knowledge broker' (2010) Science Communication 23(1), 120; see also Figure 3, KN2.

${ }^{43}$ Meyer M 'The rise of the knowledge broker' (2010) Science Communication 23(1), 123.
} 
When co-creating knowledge, stakeholders from research, policy and practice work together as partners on an equal footing. ${ }^{44}$ They start from a shared problem statement which is articulated within a specific context of time and space, rather than from a preestablished perception of problems in a policy area, profession, interest group or academic discipline. Different perspectives from each 'reservoir' of knowledge (KN1$\mathrm{KN} 2-\mathrm{KN} 3-\mathrm{KN} 4$, and so on) are brought together in a holistic and inclusive learning process, where implicit knowledge is made explicit and new knowledge (KN5) is constructed, shared and assessed to make it 'socially robust' (Figure 3). ${ }^{45}$ In such processes, the central point is not to connect pre-established perceptions and insights, but to come to as yet unarticulated solutions to complex problems that could otherwise not be found at all. As such, co-created knowledge can fulfil a role that 'traditional' knowledge has not yet been able to assume. ${ }^{46}$

Figure 3: Knowledge co-creation between multiple actors

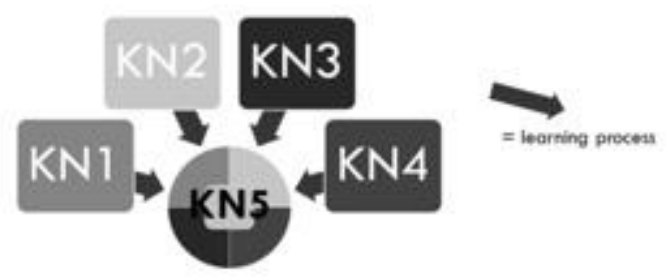

Knowledge co-creation is made operational in various ways. Usually, we speak here of long-term projects that benefit from sustainable funding and are in constant interaction with new research findings, policy needs and practitioners' feedback. As participants in F3 pointed out, however, it is indeed hard to find examples in the Flemish children's rights field where knowledge co-creation is actually happening nowadays. One person indicates that she experiences it more as 'policy, research and practice looking for each other', as a specific 'form of interaction' $;{ }^{47}$ whereas another compares it to taking up each other's signals from above (legislative level, academia) and from below (level of practice) ${ }^{48}$

One typical example is the shared praxis of 'communities of practice' or COPs, informal networks of professionals who share common problems, interests and

\footnotetext{
${ }^{44}$ As such, knowledge co-creation processes can provide an answer to imbalances of power that are present between different knowledge actors (for example, practitioners often feel like the underdog in relation to policy and research) (F2, 28:14-28:59, 1:16:08-1:17:24).

${ }^{45}$ Kassahun A, Scholten H, Beulens AJM 'Collect and share existing knowledge on collaborative multidisciplinary scientific research processes' in Kazi AS, Wohlfahrt L \& Wolf P (eds) Hands-On Knowledge Co-Creation and Sharing: Practical Methods and Techniques (2007) 351; Regeer BJ \& Bunders JFG Kenniscocreatie: samenspel tussen wetenschap \& praktijk: Complexe, maatschappelijke vraagstukken transdisciplinair benaderd (2007) 14.

${ }^{46}$ Regeer BJ \& Bunders JFG Kenniscocreatie: samenspel tussen wetenschap \& praktijk: Complexe, maatschappelijke vraagstukken transdisciplinair benaderd (2007) 16.

${ }^{47} \mathrm{~F} 3$, 4:26-5:23.

${ }^{48} \mathrm{~F} 3,11: 26-14: 31$.
} 
knowledge about the issues they encounter. ${ }^{49}$ The COP is used as a forum to communicate, manage and generate knowledge in order to preserve the results of social learning processes ${ }^{50} \mathrm{COPs}$ are directed not only towards the creation of content but the processes and networks in which the participants and the project take part. ${ }^{51}$ As such, they guarantee a widened and deepened support for creative and innovative developments combining new and existing theory and practice on a certain topic. ${ }^{52}$ Closely related to COPs are the so-called academische werkplaatsen (academic workplaces) ${ }^{53}$ Whereas such communities have been relatively well established in other fields of research, or abroad (for example, in the Netherlands), it remains a fairly new and unexplored concept in the field of Flemish children's rights. ${ }^{54}$

Another way in which the advantages of knowledge co-creation have been recognised, particularly in Flanders, is through the funding of so-called SBO projects (Strategisch Basis Onderzoek or strategic basic research). SBO funds knowledge centres and researchers to develop new ideas and concepts that can form the basis for a new generation of products, processes or services. One of the criteria for a successful application is a significant degree of interaction with as many relevant stakeholders as possible as well as proactive contribution to the process of using the results as they are released. As such, SBO differs substantially from the traditional mechanisms used in the diffusion of academic research results, such as publications, conference papers or participation in networks of academic peer groups. ${ }^{55}$

What these processes have in common is that they take stakeholders out of their comfort zone; they ask for a considerable effort to combine the best of all 'knowledges' into a new, cross-cultural experience directed towards the shared agenda that connects them. ${ }^{56}$ Such an approach is far from straightforward, especially for policy-makers, since such long-term investments are often perceived as unrealistic. ${ }^{57}$ Head nicely paraphrases this point:

\footnotetext{
${ }^{49}$ Harper C, Jones N \& Tincati C 'Opportunities and challenges in promoting policy- and practicerelevant knowledge on child rights' (2010) ODI Working Paper 318, 27; Ramalingam B The Knowledge and Learning Toolkit: A Guide for Development and Humanitarian Organisations (2005) 38.

${ }^{50}$ Magnuszewski P, Sodomkova K, Slob A, Muro M, Sendzimir J \& Pahl-Wostl C Report on Conceptual Framework for Science-Policy Barriers and Bridges (2010) 5.

${ }^{51}$ Regeer BJ \& Bunders JFG Kenniscocreatie: samenspel tussen wetenschap \& praktijk: Complexe, maatschappelijke vraagstukken transdisciplinair benaderd (2007) 15.

${ }^{52}$ Regeer BJ \& Bunders JFG Kenniscocreatie: samenspel tussen wetenschap \& praktijk: Complexe, maatschappelijke vraagstukken transdisciplinair benaderd (2007) 16.

${ }^{53} \mathrm{~F} 3$, 25:58, 33:45-35:06.

${ }^{54}$ Hermans K \& Van Regenmortel T Een empowerende academische werkplaats als innovatieve samenwerkingsvorm tussen gebruikers, praktijkwerkers, beleid en wetenschap, plenary lecture at the conference Samen Werken, 7 February 2013.

${ }^{55}$ F3, 37:27-41:03.

${ }^{56}$ Hermans K \& Van Regenmortel T Een empowerende academische werkplaats als innovatieve samenwerkingsvorm tussen gebruikers, praktijkwerkers, beleid en wetenschap, plenary lecture at the conference Samen Werken, 7 February 2013.

${ }^{57}$ F1, 02:43-03:59; F2, 05:28-06:51.
} 
We are often aware that others have important insights to complement our own perspectives, but the transaction costs of access and engagement are often so high that more cooperative approaches to knowledge and action are doomed to failure. ${ }^{58}$

Processes of knowledge co-creation can thus only take place when adequate support is offered. Such support may come from brokers and adequate financial resources, but so too training researchers in communicating about their research. ${ }^{59}$

\section{A child rights-based approach to $\mathrm{KM}$}

Having scrutinised a number of the lessons children's rights can learn from knowledge management, it is important not to overlook asking the reverse question as well namely, what KM can learn from the methodologies and know-how that have been developed in the area of children's rights over the past 25 years. In particular, as much as complex problems about the realisation of children's rights are crucial concerns to researchers, policy-makers and practitioners, first and foremost they concern children themselves. In other words, how should the dialectic processes discussed in section 3 be operationalised within the specificities of a children's rights framework, where the overall objective remains the realisation of social justice and human dignity for children and young people? Could we think of something like a children's rights-based approach $(\mathrm{CRBA})^{60}$ to $\mathrm{KM}$, where children and young people are involved in building bridges or facilitating knowledge transfers as participants, active agents and experts about their own lives?

Exercises in other contexts have shown that adopting a CRBA to a social process such as education, research or, in this case, knowledge management, means that at every stage of the activity, the realisation of children's rights is at the heart of the means (how it is done), the goal (why it is done) and the outcome (what is actually done) of the process. Taken together, this means that one can speak of a CRBA to KM when the way knowledge is framed and comes into being, what comes out of it, how it is disseminated and how this is put to use - be it in processes of academic research, policy, practice or a mixture of all - reflects that children are human beings in their own right, ${ }^{61}$

\footnotetext{
${ }^{58}$ Head B 'From knowledge transfer to knowledge sharing?' in Bammer G, Michaux A \& Sanson A (eds) Bridging the 'Know-Do' Gap: Knowledge Brokering to Improve Child Wellbeing (2010) 109.

${ }^{59} \mathrm{~F} 2,1: 17: 24-1: 19: 11$.

${ }^{60}$ Derived from the Office of the High Commissioner for Human Rights's (OHCHR (2003)) definition of Human Rights Based Approaches (HRBA), where 'human rights' can be substituted with 'children's rights', that is, the human rights of children and young people. Whereas HRBAs have most often been analysed in the context of programmes and policies directed towards development and development cooperation (that is, HRBA to development), recent studies have enlarged its scope by scrutinising its value as an approach to other activities as well, including programming (for example, by UNICEF and Save the Children), education (Reynaert (2012), Lohrenscheit (2005)), and research (Lundy \& McEvoy (2012), Ennew \& Plateau (2004)).

${ }^{61}$ Lundy L \& McEvoy (Emerson) L 'Childhood, the United Nations Convention on the Rights of the Child and research: what constitutes a rights-based approach' in Freeman M (ed) Law and Childhood
} 
'worthy of respect and dignity, who lead complex and multi-faceted lives' ${ }^{62}$ and who are, alongside adults, recognised as knowledgeable social actors. ${ }^{63}$

Whereas 'an image of children as rights holders does not in itself grant children a real capacity for action, [... the] main challenges to be identified here are for adults to recognise children as co-actors in the dialogue about their childhood, rights, choices and interests'. ${ }^{64}$ Starting from such an image of childhood thus has multiple consequences for the role children and young people can and do play in processes of KM. In particular, it challenges conventional knowledge about children's rights, which is 'constructed for the most part by adults, for other adults to use in order to make sense of, regulate and promote children's lives, growth and well-being'. ${ }^{65}$

Asking for shared ownership of the process between children and all other actors involved ${ }^{66}$ has a clear influence on traditional power balances as well. Knowledge is power, sharing knowledge is sharing power, and sharing the construction of knowledge implies sharing power relations. In processes of genuine participation, ${ }^{67}$ the traditional balance of power - according to which the adult is seen as the expert on children, on how to study children, on what to study about children and on how to interpret what children say and do - shifts towards an equilibrium in which children and adults are increasingly recognised as equal partners. ${ }^{68}$

Provided children and young people get the right support, participation has important benefits. In particular, listening to the views, concerns and experiences of children, and consequently taking these views into serious consideration as an equal source of

(2012) 77, 87; KeKi Achtergrondinformatie bij het advies voor het bestek belevingsonderzoek inzake een Kindfocus in de Stadsmonitor (2013) 3.

${ }^{62}$ Beazley H, Bessell S, Ennew J \& Waterson R 'How are the human rights of children related to research methodology?' in Invernizzi A \& Williams JM (eds) The Human Rights of Children: From Visions to Implementation (2011) 167.

${ }^{63}$ Liebel M (ed) Children's Rights from Below: Cross-Cultural Perspectives (2012) 20.

${ }^{64}$ Reynaert D, Desmet E, Lembrechts S \& Vandenhole W 'Introduction: a critical approach to children's rights' in Vandenhole W, Desmet E, Reynaert D \& Lembrechts S (eds) Routledge International Handbook of Children's Rights Studies (2015) 416, emphasis added.

${ }^{65}$ Woodhead M \& Faulkner D 'Subjects, objects or participants? Dilemmas of psychological research with children' in Christensen P \& James A Research with Children: Perspectives and Practices 2 ed (2008) 13.

${ }^{66}$ Ennew J \& Plateau DP How to Research the Physical and Emotional Punishment of Children (2004) 15; see also Hermans $\mathrm{K} \&$ Van Regenmortel $\mathrm{T}$ Een empowerende academische werkplaats als innovatieve samenwerkingsvorm tussen gebruikers, praktijkwerkers, beleid en wetenschap, plenary lecture at the conference Samen Werken, 7 February 2013; Lewig K, Arney F \& Scott D 'Closing the research-policy and research-practice gaps: ideas for child and family services' (2006) Family Matters $74,14$.

${ }^{67}$ Hart R Children's Participation: From Tokenism to Citizenship (1992).

${ }^{68}$ Hermans K \& Van Regenmortel T Een empowerende academische werkplaats als innovatieve samenwerkingsvorm tussen gebruikers, praktijkwerkers, beleid en wetenschap, plenary lecture at the conference Samen Werken, 7 February 2013; Woodhead M \& Faulkner D 'Subjects, objects or participants? Dilemmas of psychological research with children' in Christensen P \& James A Research with Children: Perspectives and Practices 2 ed (2008) 13. 
knowledge alongside other sources, ${ }^{69}$ is not only essential in ensuring the sustainability and practical usability of that knowledge, but also in creating room for alternative perspectives on the complex problem at hand. ${ }^{70}$ Attributing this active role to children can challenge dominant conceptions of what knowledge about children's rights actually is and how it can be obtained. Guiding children in this position recognises that their insights and expertise about their own situation are unique, but also that the knowledge base available about children from conventional, non-participatory sources in research, policy and practice, are in essence always partial.

In the context of children's participation in research, some have argued that one cannot speak of participation when children are simply being asked about their life worlds with the sole aim of providing adults with data. ${ }^{71}$ Consultation by means of interviews, focus groups or surveys is seen as a relatively passive process, which children merely undergo as 'research units'. ${ }^{72}$ Whereas it is true that one can hardly speak of real 'participation' in the sense of shared ownership of the entire process of knowledge generation, ${ }^{73}$ in such situations children are nevertheless more than just 'not yet competent, not yet able to reason, not yet knowledgeable, and in need of constant guidance from adults'. ${ }^{74}$ Whereas in other contexts they may be vulnerable to social exclusion, here they are

\footnotetext{
${ }^{69}$ See also F2, 02:40-03:34; F3, 08:12-11:26, 14:31, 55:06-58:14.

${ }^{70}$ Hermans K \& Van Regenmortel T Een empowerende academische werkplaats als innovatieve samenwerkingsvorm tussen gebruikers, praktijkwerkers, beleid en wetenschap, plenary lecture at the conference Samen Werken, 7 February 2013; Dedding C, Jurrius K, Moonen X, \& Rutjes L (eds) Kinderen en jongeren actief in wetenschappelijk onderzoek. Ethiek, methoden en resultaten van onderzoek met en door jeugd (2013); Harper C, Jones N \& Tincati C 'Opportunities and challenges in promoting policy- and practice-relevant knowledge on child rights' (2010) ODI Working Paper 318, 36; F2, 1:10:19.

${ }^{71}$ Beazley H, Bessell S, Ennew J \& Waterson R 'How are the human rights of children related to research methodology?' in Invernizzi A \& Williams JM (eds) The Human Rights of Children: From Visions to Implementation (2011) 163.

${ }^{72}$ Op de Beeck H, Put J \& Lembrechts S Zwaartepunten in het Vlaams Kinderrechtenonderzoek vanaf 2004: Een thematische analyse op basis van de KeKi onderzoeksdatabank (2013) 5.

${ }^{73}$ When placed in this position in the knowledge process, children are still expected to rely on adults to take account of their views. These consultations are insufficient to ensure children's participation rights; thus one cannot speak of 'active citizenship' (Van Beers H, Invernizzi A \& Milne B Beyond Article 12: Essential Readings in Children's Participation (2006)). 'If children are to achieve real benefits in their own lives and their communities, and create a better future, they can only do this by being active citizens, articulating their own values, perspectives, experiences and visions for the future, using these to inform and take action in their own right and, where necessary, contesting with those who have power over their lives' (Percy-Smith B \& Thomas N (eds) A Handbook of Children and Young People's Participation: Perspectives from Theory and Practice (2009) 3).

${ }^{74}$ Qvortrup J 'Childhood matters: an introduction' in Qvortrup J, Bardy M, Sgritta G \& Wintersberger H (eds) Childhood Matters: Social Theory, Practice and Politics (1994) 4; see also F2, 10:10-13:57.
} 
recognised as 'experts', ${ }^{75}$ 'knowers', ${ }^{76}$ and sources of knowledge who do produce knowledge about their life worlds and their rights. ${ }^{77}$

Throughout the process of knowledge management, children can play various roles in the search for new solutions to the complex problem of realising their rights. Both on a substantive level (as experts on their own lives) and on a procedural level (as brokers or bridges) ${ }^{78}$ children should be considered as active meaning-makers. Nevertheless, as the focus groups indicate, methodologies describing how children can meaningfully take up a central role in $\mathrm{KM}$ strategies have remained underdeveloped so far, ${ }^{79}$ revealing a clear need for future research in this area.

\section{Conclusion}

Without aiming to be exhaustive, this chapter has given some insights into how our knowledge on children's rights, and the mechanisms at play around it, could become better equipped to address the mess, confusion and complexity of our present reality. It has shown how different knowledge actors in the field of children's rights could benefit from know-how in the field of KM, while at the same time offer innovative approaches to $\mathrm{KM}$ on how to give children a meaningful role in such processes. As such, the chapter has aspired to launch an open-ended discussion on the challenges and opportunities of connecting both paradigms, as well as to offer a refreshing perspective on conventional ways of understanding children's rights. In conclusion, a number of critical reflections are formulated to contribute to a renewed children's rights agenda beyond the twentyfifth anniversary of the CRC.

It is true that most researchers, policy-makers and practitioners in the children's rights field genuinely care about the relevance of their research efforts, policies and programming. Equally, they care about turning their results into practice and, in one way or another, achieving the objective of social change' ${ }^{80}$ After all, creating, using, sharing and brokering knowledge in the children's rights field is based on an underlying mission of taking children and young people seriously. ${ }^{81}$ When done meaningfully,

\footnotetext{
${ }^{75}$ Dedding C, Jurrius K, Moonen X, \& Rutjes L (eds) Kinderen en jongeren actief in wetenschappelijk onderzoek. Ethiek, methoden en resultaten van onderzoek met en door jeugd (2013) 21.

${ }^{76}$ Dentith AM, Measor L \& O'Malley MP 'The research imagination amid dilemmas of engaging young people in critical participatory work' (2012) Forum: Qualitative Social Research - Sozialforschung 13(1), Art. 17.

${ }^{77}$ Hanson K \& Nieuwenhuys O 'Introduction’ in Hanson K \& Nieuwenhuys O (eds) Reconceptualizing Children's Rights in International Development: Living Rights, Social Justice, Translations (2013) 5.

${ }^{78}$ Marsh J 'Children as knowledge brokers of playground games and rhymes in the new media age' (2012) Childhood 19(4), 508-22.

${ }^{79} \mathrm{~F} 2,02: 40-03: 34$.

${ }^{80}$ Lundy L \& McEvoy (Emerson) L 'Childhood, the United Nations Convention on the Rights of the Child and research: what constitutes a rights-based approach' in Freeman M (ed) Law and Childhood (2012) 78 .

${ }^{81} \mathrm{~F} 2,1: 12: 23-1: 13: 01$.
} 
genuinely, actively and effectively, ${ }^{82}$ participatory processes in particular can enhance the potential for knowledge actors to make a positive difference to children's lives. ${ }^{83}$

In order for such an impact to be positive and constructive, however, the quality of different sources of knowledge needs to be critically examined. For example, it is obvious that the quality and reliability of the information and data that lie at the basis of a knowledge-based children's rights system have a profound impact on how research, policies and programmes fulfilling children's rights will function. ${ }^{84}$ Complex problems thus not only require the participation of different stakeholders, but also the consideration of specific methodological choices. Beazley et al. have established that policy-makers and planners tend to over-rely on quantitative data collection, leaving little room for open-ended answers in a way that is more systematic than just single stories or anecdotes. ${ }^{85}$ Using a variety of methods, they suggest, would increase opportunities to gain deeper insights ${ }^{86}$ and consequently improve the chances of making a positive impact on children's lives.

Following the lead of Campbell and Fiske, and Harper et al., ${ }^{87}$ Regeer and Bunders and $\mathrm{KeKi}^{88}$ recommend the use of mixed-method approaches in child-related policymaking, combining quantitative and qualitative research methods as well as children's experiences, so as to come to knowledge that is 'robust' and valuable not only from the perspective of the researcher but also of the policy-maker and practitioner. ${ }^{89}$ The Committee on the Rights of the Child has also in its General Comment No. 5 (2003, $\S 48)$ explicitly encouraged states to 'collaborate with appropriate research institutes

\footnotetext{
${ }^{82}$ Dedding C, Jurrius K, Moonen X, \& Rutjes L (eds) Kinderen en jongeren actief in wetenschappelijk onderzoek. Ethiek, methoden en resultaten van onderzoek met en door jeugd (2013) 14; Hart R Children's Participation: From Tokenism to Citizenship (1992).

${ }^{83}$ Lundy L \& McEvoy (Emerson) L 'Childhood, the United Nations Convention on the Rights of the Child and research: what constitutes a rights-based approach' in Freeman M (ed) Law and Childhood (2012) 91.

${ }^{84}$ Ennew J 'Has research improved the human rights of children? Or have the information needs of the CRC improved data about children?' in Williams J \& Invernizzi A (eds) The Human Rights of Children: From Visions to Implementation (2011) 133.

${ }^{85}$ Beazley H, Bessell S, Ennew J \& Waterson R 'How are the human rights of children related to research methodology?' in Invernizzi A \& Williams JM (eds) The Human Rights of Children: From Visions to Implementation (2011) 169.

${ }^{86}$ Beazley H, Bessell S, Ennew J \& Waterson R 'How are the human rights of children related to research methodology?' in Invernizzi A \& Williams JM (eds) The Human Rights of Children: From Visions to Implementation (2011) 169.

${ }^{87}$ Harper C, Jones N \& Tincati C 'Opportunities and challenges in promoting policy- and practicerelevant knowledge on child rights' (2010) 31-2

${ }^{88}$ Regeer BJ \& Bunders JFG Kenniscocreatie: samenspel tussen wetenschap \& praktijk: Complexe, maatschappelijke vraagstukken transdisciplinair benaderd (2007) 16; KeKi Achtergrondinformatie bij het advies voor het bestek belevingsonderzoek inzake een Kindfocus in de Stadsmonitor (2013) 11-14. ${ }^{89}$ This need was also confirmed during the focus groups, in particular at F2, 28:59-30:14 \& F3, 06:2308:12, 1:28:13-1:29:26, 1:37:15-1:37:58.
} 
and aim to build up a complete picture of progress towards implementation, with qualitative as well as quantitative studies'. ${ }^{90}$

Finally, as Ennew has argued, '[t]he greatest violation of children's rights is that we do not know enough about their lives, or care enough to find out more'. ${ }^{91}$ While this chapter has shown that knowledge sharing and co-creation can be part of the solution to bridge children's rights between research, policy, practice and children themselves, it must be clear that KM is not in itself a panacea for the social problems underlying violations of children's rights. ${ }^{92}$ Knowledge has clear limits. Rather than being an endpoint, however, these limitations entail a call to action for all stakeholders involved in the process of knowledge affecting the realisation of children's rights. These limits invite stakeholders to identify and tackle the barriers to children's rights that they do know and experience, first and foremost within the small-scale complexity of their own island, but also, increasingly, beyond their professional or institutional borders. In addition, it invites them to continue confronting 'their' knowledge with that of others, in a dynamic dialogue, cooperatively, and through new or existing 'bridges', to form new and adapted ways of understanding, knowing and ultimately solving complex problems relating to the realisation of children's rights.

\section{Bibliography}

\section{Books}

Bammer G, Michaux A \& Sanson A Bridging the 'Know-Do' Gap: Knowledge Brokering to Improve Child Wellbeing (2010) Canberra: ANU Press.

Dedding C, Jurrius K, Moonen X, \& Rutjes L (eds) Kinderen en jongeren actief in wetenschappelijk onderzoek. Ethiek, methoden en resultaten van onderzoek met en door jeugd (2013) Houten: Uitgeverij Lannoo Campus.

Ennew J \& Plateau DP How to Research the Physical and Emotional Punishment of Children (2004) Bangkok: Save the Children.

Glaser BG \& Strauss AL The Discovery of Grounded Theory: Strategies for Qualitative Research (1967) Chicago: Aldine Publishing Company.

Kazi AS, Wohlfahrt L \& Wolf P (eds) Hands-On Knowledge Co-Creation and Sharing: Practical Methods and Techniques (2007) Stuttgart: Knowledge Board.

\footnotetext{
90 See also Lundy \& McEvoy Lundy L \& McEvoy (Emerson) L 'Childhood, the United Nations Convention on the Rights of the Child and research: what constitutes a rights-based approach' in Freeman M (ed) Law and Childhood (2012) 75.

${ }^{91}$ Ennew J 'Has research improved the human rights of children? Or have the information needs of the CRC improved data about children?' in Williams J \& Invernizzi A (eds) The Human Rights of Children: From Visions to Implementation (2011) 154.

${ }^{92}$ Stone D 'Using knowledge: the dilemmas of 'bridging research and policy''(2002) Compare 32(3), 285.
} 
Liebel M (ed) Children's Rights from Below: Cross-Cultural Perspectives (2012) New York: Palgrave.

Percy-Smith B \& Thomas N (eds) A Handbook of Children and Young People's Participation: Perspectives from Theory and Practice (2009) New York: Routledge.

Van Beers H, Invernizzi A \& Milne B Beyond Article 12: Essential Readings in Children's Participation (2006) Bangkok: Knowing Children.

\section{Chapters in books}

Beazley H, Bessell S, Ennew J \& Waterson R 'How are the human rights of children related to research methodology?' in Invernizzi A \& Williams JM (eds) The Human Rights of Children: From Visions to Implementation (2011) Farnham: Ashgate 159-78.

Ennew $\mathbf{J}$ 'Has research improved the human rights of children? Or have the information needs of the CRC improved data about children?' in Williams J \& Invernizzi A (eds) The Human Rights of Children: From Visions to Implementation (2011) Aldershot: Ashgate.

Hanson K \& Nieuwenhuys O 'Introduction' in Hanson K \& Nieuwenhuys O (eds) Reconceptualizing Children's Rights in International Development: Living Rights, Social Justice, Translations (2013) Cambridge University Press, 3-25.

Head B 'From knowledge transfer to knowledge sharing?' in Bammer G, Michaux A \& Sanson A (eds) Bridging the 'Know-Do' Gap: Knowledge Brokering to Improve Child Wellbeing (2010) Canberra: ANU Press, 109-24.

Kassahun A, Scholten H, Beulens AJM 'Collect and share existing knowledge on collaborative multidisciplinary scientific research processes' in Kazi AS, Wohlfahrt L \& Wolf P (eds) Hands-On Knowledge Co-Creation and Sharing: Practical Methods and Techniques (2007) Stuttgart: Knowledge Board, 347-62.

Lundy L \& McEvoy (Emerson) L 'Childhood, the United Nations Convention on the Rights of the Child and research: what constitutes a rights-based approach' in Freeman M (ed) Law and Childhood (2012) Oxford: Oxford University Press, 75-91.

Qvortrup J 'Childhood matters: an introduction' in Qvortrup J, Bardy M, Sgritta G \& Wintersberger H (eds) Childhood Matters: Social Theory, Practice and Politics (1994) Avebury: Aldershot.

Reynaert D, Desmet E, Lembrechts S \& Vandenhole W 'Introduction: a critical approach to children's rights' in Vandenhole W, Desmet E, Reynaert D \& Lembrechts S (eds) Routledge International Handbook of Children's Rights Studies (2015) London: Routledge (in press). 
Vandenhole W 'Localizing the human rights of children' in Liebel M (ed) Children's Rights from Below: Cross-cultural Perspectives (2012) New York: Palgrave, 80-93.

Woodhead M \& Faulkner D 'Subjects, objects or participants? Dilemmas of psychological research with children' in Christensen P \& James A Research with Children: Perspectives and Practices 2 ed (2008) New York: Routledge, 10-39.

\section{Journal articles}

Campbell DT \& Fiske DW 'Convergent and discriminant validation by the multitrait multimethod matrix’ (1959) Psychological Bulletin 56(2), 81-105.

Dentith AM, Measor L \& O'Malley MP 'The research imagination amid dilemmas of engaging young people in critical participatory work' (2012) Forum: Qualitative Social Research - Sozialforschung 13(1), Art. 17.

Lewig K, Arney F \& Scott D 'Closing the research-policy and research-practice gaps: ideas for child and family services’ (2006) Family Matters 74, 12-19.

Lundy L \& McEvoy (Emerson) L 'Children's rights and research processes: assisting children to (in)formed views' (2012) Childhood 19(1) 116-29.

Marsh J 'Children as knowledge brokers of playground games and rhymes in the new media age' (2012) Childhood 19(4), 508-22.

Meyer M 'The rise of the knowledge broker' (2010) Science Communication 23(1), 118-27.

Reynaert D, Bouverne-De Bie M \& Vandevelde S 'Children, rights and social work: rethinking children's rights education' (2010) Social Work and Society: International Online Journal 8(1), 60-9.

Shonkoff JP 'Science, policy and practice: three cultures in search of a shared mission' (2000) Child Development 71(1), 181-87.

Sin Chih $\mathrm{H}$ 'The role of intermediaries in getting evidence into policy and practice: some useful lessons from examining consultancy-client relationships' (2008) Evidence \& Policy: A Journal of Research, Debate and Practice 4(1), 85-103.

Stone D 'Using knowledge: the dilemmas of 'bridging research and policy' (2002), Compare 32(3), 285-96.

Waddell C 'So much research evidence, so little dissemination and uptake: mixing the useful with the pleasing' (2001) Evidence Based Mental Health 4(1), 3-5.

Young J 'Impact of research on policy and practice' (2008) Capacity 35 feature series Working with Complexity, available at 
http://r4d.dfid.gov.uk/PDF/Articles/YoungImpactofResearch.pdf (accessed 13 January 2016).

\section{Papers}

Crow MM 'None dare call it hubris: the limits of knowledge' (2007) Perspectives available at http://step.berkeley.edu/Journal_Club/paper3_092210.pdf (accessed 6 January 2016).

Court J \& Young J 'Bridging research and policy: insights from 50 case studies' (2003) ODI Working Paper 213, available at http://www.odi.org.uk/sites/odi.org.uk/files/odiassets/publications-opinion-files/180.pdf (accessed 6 January 2016).

Court $\mathrm{J}$ \& Young $\mathrm{J}$ 'Bridging research and policy in international development: an analytical and practical framework' (2004) ODI Briefing Paper, available at http://www.odi.org.uk/sites/odi.org.uk/files/odi-assets/publications-opinionfiles/198.pdf (accessed 13 January 2016).

Harper C, Jones N \& Tincati C 'Opportunities and challenges in promoting policy- and practice-relevant knowledge on child rights' (2010) ODI Working Paper 318, available at http://www.odi.org.uk/sites/odi.org.uk/files/odi-assets/publications-opinionfiles/6050.pdf (accessed 6 January 2016).

Lohrenscheit C 'A human rights based approach to education' (2005) German Institute for Human Rights, formerly available at http://www.irmgard-coninxstiftung.de/fileadmin/user_upload/pdf/archive/Claudia_Lohrenscheit.pdf (accessed 6 January 2016).

\section{Reports}

Magnuszewski P, Sodomkova K, Slob A, Muro M, Sendzimir J \& Pahl-Wostl C Report on Conceptual Framework for Science-Policy Barriers and Bridges (2010) Final version of deliverable No. 1.1 of the EC FP7 project PSI-connect. EC contract No. 226915, Delft, the Netherlands. Available at https://www.researchgate.net/profile/Adriaan_Slob/publication/230557654_Report_o n_conceptual_framework_for_science-

policy_barriers_and_bridges/links/0912f50be2b979f545000000.pdf (accessed 17 February 2016).

Regeer BJ \& Bunders JFG Kenniscocreatie: samenspel tussen wetenschap \& praktijk: Complexe, maatschappelijke vraagstukken transdisciplinair benaderd (2007) RMNO report, available at http://www.sg.uu.nl/prog/2010b/docs/kenniscocreatie.pdf (accessed 15 January 2015). 
UNICEF Progress Report and Proposed Activities for 2006-2008 (2005) New York: UNICEF, available at http://www2.unicef.org:60090/about/execboard/files/0513_Innocenti.pdf (accessed 13 January 2016).

\section{Miscellaneous}

Committee on the Rights of the Child, General Comment No. 5 (2003) General Measures of Implementation of the Convention on the Rights of the Child, UN Doc. $\mathrm{CRC} / \mathrm{GC} / 2003 / 5$.

Comiskey $\mathrm{C}$ Developing and implementing a model to bridge the gap in policy research and practice (2012) recordings, available at http://www.psihq.ie/psi-child-adolescentpsychology (accessed 13 January 2016).

Girard J Knowledge Management (KM) Definitions (2015) available at http://www.johngirard.net/km (accessed 13 January 2015).

Hart R Children's Participation: From Tokenism to Citizenship (1992) Innocenti Research Centre, available at http://www.unicefirc.org/publications/pdf/childrens_participation.pdf (accessed 6 January 2016).

Hermans K \& Van Regenmortel T Een empowerende academische werkplaats als innovatieve samenwerkingsvorm tussen gebruikers, praktijkwerkers, beleid en wetenschap, plenary lecture at the conference Samen Werken, 7 February 2013, Antwerp: Jeugdzorg Emmaus.

KeKi Achtergrondinformatie bij het advies voor het bestek belevingsonderzoek inzake een Kindfocus in de Stadsmonitor (2013) available at http://www.keki.be/sites/default/files/Belevingsonderzoek\%20stadsmonitor\%20\%20Achtergrond.pdf (accessed 13 January 2016).

Office of the High Commissioner for Human Rights (OHCHR) The Human Rights Based Approach to Development Cooperation: Towards a Common Understanding Among UN Agencies (2003) available at http://hrbaportal.org/the-human-rights-basedapproach-to-development-cooperation-towards-a-common-understanding-among-unagencies (accessed 13 January 2016).

Op de Beeck H, Put $\mathrm{J} \&$ Lembrechts $\mathrm{S}$ Zwaartepunten in het Vlaams Kinderrechtenonderzoek vanaf 2004: Een thematische analyse op basis van de KeKi onderzoeksdatabank (2013) Gent: Kenniscentrum Kinderrechten vzw.

Ramalingam B The Knowledge and Learning Toolkit: A Guide for Development and Humanitarian Organisations (2005), ODI, available at http://www.odi.org.uk/sites/odi.org.uk/files/odi-assets/publications-opinionfiles/188.pdf (accessed 13 January 2016). 